\title{
Selection of mother tongue on ethnic Osing family (Sociolinguistic and ethnographic communication studies)
}

\author{
Memmy Dwi Jayanti*) \\ Universitas Indraprasta PGRI \\ *) Correspondences author: Jalan Raya Tengah No. 80, RT.9/RW.8, Gedong, Pasar Rebo, RT.1/RW.3, Gedong, \\ Kota Jakarta Timur, Daerah Khusus Ibukota Jakarta 13760, Indonesia; \\ e-mail: memmydj@gmail.com
}

\begin{abstract}
The purpose of this study to describe the language selection mom used ethnic Osing Giri in the distric, the village of Penataban, Banyuwangi-East Java. The language used is the language communities in Banyuwangi Osing, Java, and Madura for the third ethnic coexistence. Womg Osing or Lare Osing is a native of Banyuwangi, Osing language is a direct descendant of the ancient Javanese language yet very different dialect. The method used is descriptive method of providing data refer capably involved (SLC), consider ably involved free (SBLC), and interview. The results showed that the choice of language on ethnic family Osing Indonesian in there is an influence in terms of education and employment. Indonesia introduced the use of language in children is the language used in everyday family. Such circumstances indicate that the Indonesian experience growth in public life, expecially in rural districts Penataban Giri, Banyuwangi
\end{abstract}

Keywords: Language Selection, Osing Family, Mother Tongue.

Article History: Received: 15/02/2017; Revised: 23/03/2017; Accepted: 16/04/2017; Published: 05/05/2017

How to Cite (MLA $7^{\text {th)}): ~ J a y a n t i, ~ M e m m y ~ D w i . ~ “ S e l e c t i o n ~ o f ~ m o t h e r ~ t o n g u e ~ o n ~ e t h n i c ~ O s i n g ~ f a m i l y ~(S o c i o l i n g u i s t i c ~ a n d ~}$ Ethnographic Communication Studies)." Hortatori: Jurnal Pendidikan Bahasa dan Sastra Indonesia 1.1 (2017): 74-78. Print/Online. Copyrights Holder: Jayanti, Memmy Dwi. First Publication: Hortatori Jurnal Pendidikan Bahasa dan Sastra Indonesia (2017).

This work is licensed under a Creative Commons Attribution-ShareAlike 4.0 International License.

\section{Pendahuluan}

Manusia sebagai makhluk sosial selalu berhubungan antarmanusia satu dengan yang lainnya dengan tujuan untuk memenuhi kebutuhan hidupnya. Proses interaksi dan komunikasi akan berjalan dengan baik jika adanya suatu bahasa, penggunakan bahasa dalam berkomunikasi sangat penting sebagai media untuk menyampaikan informasi, ide, atau gagasan baik melalui ekspresi lisan dan tulis. Di negara Indonesia kedudukan bahasa Indonesia sebagai bahasa nasional dan bahasa negara semakin kuat. Hal ini ditunjukkan dengan semakin besar dan luasnya domain pemakaiannya. Meluasnya pemakai bahasa Indonesia berarti bahasa Indonesia semakin memasyarakat. Artinya, secara tidak langsung menunjukkan semakin tinggi pula kesadaran masyarakat akan pentingnya bahasa Indonesia.

Pemakaian bahasa Indonesia yang terjadi di luar daerah Ibukota Jakarta kenyataanya adalah pemakaian bahasa Indonesia yang dilakukan di lingkungan keluarga. Maksudnya, ketika ayah dan ibu berkomunikasi menggunakan bahasa daerah sebagai bahasa mereka sedangkan untuk berkomunikasi dengan anak-anak mereka beralih dengan menggunakan bahasa Indonesia. Hal tersebut menunjukkan adanya pergeseran domain pemakaian bahasa, yaitu dalam komunikasi ranah keluarga. Meluasnya pemakaian bahasa Indonesia, terutama dalam lingkungan keluarga tentunya tidak lepas dari semakin tingginya perkembangan teknologi dan kemajuan informasi yang mendukung pemakaian bahasa itu sendiri. 
Selain itu, bahasa dan pemakaiannya dipengaruhi oleh beberapa faktor antara lain: status sosial, tingkat pendidikan, usia, tingkat ekonomi, jenis kelamin, dan sebagainya. Di samping itu, pemakaian bahasa juga dipengaruhi oleh faktor situasional, yaitu siapa berbicara, dengan bahasa apa, kepada siapa, kapan, di mana, dan mengenai apa. Faktor sosial dan faktor situasional tersebut menimbulkan variasi-variasi bahasa dan perubahan pemakaian bahasa Indonesia dalam keluarga (Suwito, 1993).

Suku Osing merupakan penduduk asli Banyuwangi karena suku Osing adalah masyarakat yang hidup pada pemerintahan kerajaan Blambangan, bahasa Osing merupakan turunan langsung dari bahasa Jawa Kuno namun bukan bahasa Jawa karena memiliki dialek yang berbeda. Salah satu keunikan di kota Banyuwangi adalah penduduknya yang terdiri dari beberapa etnik seperti masyarakat Jawa, Madura, dan Osing. Walaupun hidup berdampingan namun suku Osing memiliki adat istiadat budaya dan bahasa yang berbeda dari masyarakat Jawa dan Madura.

Beberapa Kecamatan yang terdapat di Kabupaten Banyuwangi antara lain: Kecamatan Rogojampi, Sempu, Glagah, Kalipuro, Giri, dan sebagainya. Kecamatan Giri terdapat desa Penataban yang merupakan kecamatan kota dan mempunyai kondisi yang berbeda baik kondisi ekonomi, sosial, pendidikan, budaya, dan sebagainya. Perbedaan tersebut menimbulkan dampak positif terutama yang berkaitan dengan situasi dan kondisi kebahasaan yang digunakan oleh masyarakat Penataban, yaitu pemakaian bahasa Indonesia dalam domain keluarga. Adanya kecenderungan pemakaian bahasa Indonesia oleh masyarakat di Kecamatan Giri desa Penataban, khususnya pada keluarga etnik Osing saat ini. Kecenderungan tersebut dapat dilihat dari semakin banyaknya anak-anak usia prasekolah yang telah dapat berbahasa Indonesia. Ini berkaitan dengan adanya kecenderungan orang tua memilih dan memperkenalkan bahasa Indonesia pada anak-anak mereka. Keadaan ini diduga dipengaruhi oleh latar belakang keluarga, seperti latar belakang pendidikan orang tua dan pekerjaan orang tua. Mata pencaharian suku Osing adalah bertani, di desa Penataban sebagian penduduknya adalah bertani dan pedagang pekerjaan di bidang formal yaitu bekerja sebagai karyawan seperti guru dan karyawan Pemda, berdasarkan hasil pengamatan itulah faktor-faktor sosial juga memengaruhi.

Dengan demikian orang tua mempunyai peranan besar dalam perubahan-perubahan yang terjadi dalam masyarakat berkaitan dengan pemakaian bahasa Indonesia dalam komunikasi keluarga. Orang tua telah memperkenalkan bahasa Indonesia kepada anak-anak mereka ketika masih dalam usia kanak-kanak, sehingga anak mengenal bahasa Indonesia sebagai bahasa pertamanya.

\section{Metode}

Metode yang digunakan dalam penelitian ini yaitu metode deskriptif kualitatif, wawancara, serta kajian kebahasaan sosiolinguistik, yaitu teori yang menempatkan kedudukan bahasa dalam lingkungannya dengan pemakaiannya di dalam masyarakat. Pada tahap pengumpulan data untuk mengetahui latar belakang sosial keluarga menyangkut hal-hal yang berkaitan dengan identitas informan yang meliputi: pendidikan, pekerjaan, status dalam keluarga, jumlah anak, suku atau etnik dan tempat tinggal informan. Latar belakang kebahasaan keluarga adalah latar belakang bahasa yang digunakan dalam komunikasi keluarga, dalam hal ini orang tua dianggap mempunyai pengaruh yang besar terhadap pemakaian bahasa dalam komunikasi keluarga.).

\section{Hasil dan Diskusi}

\section{Hasil}

Faktor sosial keluarga yang dibahas dalam penelitian ini adalah faktor pendidikan orang tua dan pekerjaan yang dianggap mempunyai pengaruh terhadap pemilihan bahasa keluarga, karena pada bahasa keluarga ini yang nantinya akan membentuk bahasa ibu pada anak. Apabila orang tua memilih bahasa Osing sebagai komunikasi dalam keluarga sesuai dengan etnisnya, maka anak akan mengenal bahasa pertamanya adalah bahasa Osing. Demikian juga sebaliknya, apabila orang tua memilih berkomunikasi menggunakan bahasa Indonesia karena mendapat pengaruh dari lingkungan pendidikan atau pekerjaan orang tua, mereka diharuskan menggunakan bahasa Indonesia yang akhirnya terbawa hingga ke dalam ranah keluarga. Maka bahasa yang dikenal pada anak adalah bahasa Indonesia, sehingga bahasa inilah yang menjadi bahasa ibu pada anak. 


\section{Faktor Pendidikan Orang Tua terhadap Pemilihan Bahasa Keluarga pada Keluarga Etnik Osing}

\begin{tabular}{lccccc}
\hline No. & Kelompok & BO & BI & \multicolumn{2}{c}{ Persentase } \\
\cline { 4 - 6 } & & & & PBO & PBI \\
1. & KPR & 21 & 9 & 70 & 30 \\
2. & KPT & 11 & 19 & 36,7 & 63,3 \\
& Jumlah & 32 & 28 & 106,7 & 93,3 \\
\hline
\end{tabular}

Keterangan:

Keluarga Pendidikan Rendah (KPR)

Keluarga Pendidikan Tinggi (KPT)

Pada tabel di atas dijelaskan bahwa pendidikan sangat berpengaruh terhadap pemilihan bahasa seseorang. Keluarga etnik Osing yang orang tuanya berpendidikan minimal Sekolah Dasar (SD) hingga Sekolah Menengah Pertama (SMP) dikategorikan dalam kelompok keluarga berpendidikan rendah (KPR), sedangkan keluarga yang berpendidikan minimal Sekolah Menengah Umum (SMU) hingga Perguruan Tinggi (PT), maka dikelompokkan dalam keluarga pendidikan tinggi (KPT). Pengumpulan data faktor sosial pendidikan dilakukan secara acak (random sampling) dengan jumlah informan 60 keluarga, yang terbagi atas 30 keluarga berpendidikan rendah dan 30 keluarga berpendidikan tinggi.

Berdasarkan penelitian lapangan, didapatkan bahwa kelompok KPR cenderung lebih memilih menggunakan bahasa Osing dalam berkomunikasi pada ranah keluarga. Sebaliknya kelompok KPT menunjukkan persentase yang tinggi daripada KPR terhadap pemilihan bahasa Indonesia sebagai bahasa keluarga pada keluarga etnik Osing di Desa Penataban, Kecamatan Giri. Hal tersebut karena KPR yang mempunyai pendidikan Sekolah Dasar (SD) hingga Sekolah Menengah Pertama (SMP) menguasai bahasa Indonesia relatif sedikit atau kecil, sehingga sebagian besar dari kelompok KPR cenderung memilih menggunakan bahasa Osing daripada bahasa Indonesia di dalam kehidupan sehari-harinya. Untuk kelompok KPT yang mempunyai pendidikan minimal SMA memeroleh pengetahuan tentang bahasa Indonesia yang berbeda dengan kelompok KPR. Mereka mempunyai tingkat pemahaman yang lebih tinggi tentang peran dan permasalahan bahasa. Selain itu, pada diri mereka terdapat rasa bangga menggunakan bahasa Indonesia dan mereka sudah terbiasa terlatih dengan penggunaan bahasa Indonesia dalam lingkungan sekolah yang formal dengan intensitas penggunaan bahasa Indonesia yang cukup banyak. Tanpa mereka sadari, kebiasaan tersebut terbawa ke komunikasi pada ranah keluarga. Hal ini didukung pula oleh keadaan dan situasi kebahasaan, di mana bahasa Indonesia saat ini sesuai untuk digunakan dalam kehidupan sehari-hari.

\section{Faktor Pekerjaan Orang Tua terhadap Pemilihan Bahasa Keluarga pada Keluarga Etnik Osing.}

\begin{tabular}{lccccc}
\hline No. & Kelompok & BO & BI & \multicolumn{2}{c}{ Persentase } \\
\cline { 5 - 6 } & & & & PBO & PBI \\
1. & KPt & 17 & 3 & 85 & 15 \\
2. & KPd & 12 & 8 & 60 & 40 \\
3. & KPk & 11 & 9 & 55 & 45 \\
& Jumlah & 40 & 20 & 200 & 100 \\
\hline
\end{tabular}

Keterangan:

a. Keluarga Petani (KPt)

b. Keluarga Pedagang (KPd)

c. Keluarga Karyawan (KPk) 
Berdasarkan tabel di atas dapat dijelaskan bahwa pengaruh pekerjaan orang tua terhadap pemilihan bahasa keluarga pada penelitian ini terbagi menjadi tiga kelompok, yaitu kelompok keluarga petani (KPt), kelompok keluarga pedagang (KPd), dan kelompok keluarga karyawan (KPk). Jumlah informan yang digunakan sebanyak 60 keluarga, yang terbagi atas keluarga yang mempunyai latar belakang sosial pekerjaan sebagai petani, pedagang, dan karyawan yang masing-masing berjumlah 20 kepala keluarga. Berdasarkan hasil penelitian, diperoleh keterangan bahwa terdapat kecenderungan yang berbeda dari ketiga kelompok tersebut. Pemakaian bahasa Indonesia yang digunakan di dalam lingkungan pekerjaan dan keadaan masyarakat mempunyai pengauh sekitar serta situasi kebahasaan yang berlaku di lingkungan pekerjaan masing-masing.

Keluarga KPt mempunyai kehidupan yang tradisional dan lebih memerhatikan norma-norma yang berlaku dalam masyarakat sekitarnya. Mereka masih menjunjung tinggi nilai-nilai adat istiadat Osing yang berlaku dalam masyarakat. Dilihat dari aspek kebahasaannya, mereka cenderung memilih bahasa yang berlaku di dalam masyarakatnya, yaitu bahasa Osing. Keluarga KPd masih cenderung memilih bahasa Osing sebagai bahasa keluarga dengan ditunjukkan terdapatnya sejumlah besar keluarga yang memilih bahasa Osing. Hal tersebut dikarenakan dalam jiwa mereka sudah tertanam adat dan istiadat budaya Osing, sehingga hanya sebagian kecil KPd yang memilih bahasa Indonesia sebagai bahasa keluarga. Dengan demikian anak yang berbahasa ibu bahasa Indonesia dalam KPd masih relatif terbatas. Keluarga KPk intensitas berkomunikasi dengan masyarakat luas jauh lebih banyak. Tuntutan kedinasan yang menuntut sikap formal membuat kelompok ini lebih sering menggunakan bahasa Indonesia daripada bahasa Osing di lingkungan pekerjaannya. Dengan demikian, keluarga dalam kelompok ini dalam menjalin hubungan dengan anggota masyarakatnya, baik dengan masyarakat luas dan masyarakat dalam lingkungan pekerjaannya dituntut mempunyai mobilitas yang tinggi dan akhirnya struktur sosialnya bersifat heterogen.

Berdasarkan hasil penelitian diperoleh keterangan bahwa terdapat pengaruh faktor sosial pada pemilihan bahasa keluarga pada keluarga etnik Osing di Kecamatan Giri. Hal tersebut menyebabkan adanya pemilihan salah satu bahasa, yaitu bahasa Osing atau bahasa Indonesia yang akan digunakan dalam komunikasi keluarga. Pendidikan orang tua berpengaruh terhadap pemilihan bahasa, hal tersebut terlihat bahwa KPR mempunyai kecenderungan memilih bahasa Osing daripada bahasa Indonesia. Demikian juga pada KPT, diantara kedua kelompok tersebut terdapat persentase yang berbeda, yaitu pada KPR terdapat selisih $49 \%$ antara keluarga yang memilih bahasa Osing dengan keluarga yang memilih bahasa Indonesia sebagai bahasa keluarga. Pada KPT, terdapat 25\%selisih yang terjadi antara keluarga yang cenderung memilih bahasa Indonesia sebagai bahasa keluarga. Dengan demikian, terlihat bahwa pendidikan mempunyai pengaruh terhadap pemilihan bahasa yang digunakan dalam lingkungan keluarga. Dalam lingkungan keluarga yang memilih menggunakan bahasa Osing dalam komunikasi ranah keluarga, maka anak akan mengenal bahasa Osing sebagai bahasa pertamanya. Sebaliknya, jika keluarga yang cenderung menggunakan bahasa Indonesia sebagai bahasa keluarga, maka bahasa pertama yang dikenal anak adalah bahasa Indonesia.

Berdasarkan aspek pekerjaan orang tua, karena secara tidak langsung berpengaruh pada kecenderungan pemilihan bahasa dalam lingkungan ranah keluarga. Kelompok KPt mempunyai kecenderungan yang kuat dalam memilih bahasa, mereka cenderung menggunakan bahasa Osing dalam ranah komunikasi keluarga. Keluarga yang memilih bahasa Indonesia dalam kelompok KPt yaitu terdapat $60 \%$ selisih di antara keduanya, sedangkan pada kelompok KPd terdapat 44,6\%, dan kelompok KPk sebesar $15 \%$. Hal ini menunjukkan bahwa pekerjaan yang berbeda menyebabkan pengaruh berbeda pula terhadap pemilihan bahasa keluarga, sehingga menyebabkan bahasa pertama yang akan dikenal anak tersebut sesuai dengan bahasa yang dipilih orang tua. 


\section{Perbedaan Gaya Penggunaan Bahasa}

\begin{tabular}{cccc}
\hline No & BO & BJ & BI \\
\hline 1. & Gedigau & Ngono & Begitu \\
2. & Asau & Asu & Anjing \\
3. & Isun arep menyang & Aku kate & Saya akan \\
& & lungo & pergi \\
4. & Siro wes madyang? & Kowe wes & Kamu sudah \\
& mangan? & makan? \\
5. & Ojok byakalan & Ojok & Jangan pacaran \\
& sulung! & pacaran & dulu! \\
6. & Ojok gedigai & Ojok ngene & Jangan begini! \\
& & ki! & \\
\hline
\end{tabular}

Bahasa Osing mempunyai banyak kesamaan dan memiliki kosakata Bahasa Jawa Kuna yang masih tertinggal. Namun, bahasa Osing mempunyai keunikan dalam sistem pelafalannya seperti adanya diftong [ai] untuk vokal [i] contoh tabel di atas kata gedigai, diftong [au] untuk vokal [u], leksikon berakhiran "u" hampir selalu terbaca "au" contoh di atas merujuk kata Asau, gedigau dan penggunaan palatalisasi [y] dalam bahasa Osing dicontohkan kata madyang, byakalan.

\section{Simpulan}

Pemilihan bahasa Indonesia sebagai bahasa ibu dipengaruhi latar belakang pekerjaan orang tua. Artinya, keluarga yang bekerja sebagai petani memiliki kecenderungan yang rendah dalam memilih bahasa Indonesia sebagai bahasa keluarga, ditunjukkan dengan terdapatnya 10\% keluarga yang memilih bahasa Indonesia. Keluarga yang orang tuanya sebagai pedagang menunjukkan kecenderungan yang cukup atau sedang dalam penggunaan bahasa Indonesia sebagai bahasa keluarga, yaitu terdapat 23,6\%, sedangkan keluarga karyawan menunjukkan kecenderungan yang sangat tinggi, yaitu terdapat $43 \%$ keluarga yang memilih bahasa Indonesia. Dapat disimpulkan bahwa semakin tinggi tingkat pendidikan orang tua, maka semakin tinggi kecenderungan keluarga tersebut memilih bahasa Indonesia sebagai bahasa keluarga. Sebaliknya, semakin rendah tingkat pendidikan orang tua, maka semakin rendah kecenderungan keluarga tersebut memilih bahasa Indonesia. Selain itu, dari latar belakang pendidikan orang tua disimpulkan bahwa keluarga yang orang tuanya berpendidikan tinggi memiliki kecenderungan memilih bahasa Indonesia daripada keluarga yang berpendidikan rendah.

\section{Ucapan Terima Kasih}

Terima kasih kepada semua pihak yang membantu penulis dalam menyelesaikan artikel hasil riset ini sehingga bisa diterbitkan di Jurnal Hortatori.

\section{Daftar Rujukan}

Chaer, A. dan Agustina L. Sosiolinguistik perkenalan awal. Jakarta: PT Rineka Cipta, 2004. Print.

Keraf, G. Tata bahasa Indonesia: untuk sekolah lanjutan atas. Ende: Nusa Indah, 1998. Print.

Suwito. Sosiolinguistik teori dan problem. Surakarta: Fakultas Sastra Universitas Sebelas Maret, 1993.

Print.

Sumarsono dan Paina P. Sosiolinguistik. Yogyakarta: Pustaka Pelajar, 2004. Print.

Soehartono, I. Metode penelitian sosial: suatu teknik penelitian bidang kesejahteraan sosial ilmu sosial lainnya. Bandung: Remaja Rosdakarya, 1995. Print.

Soejatno, A. Psikologi perkembangan. Jakarta: Aksara Baru, 2006. Print.

Tarigan, H.G. Pengajaran semantik. Bandung: Angkasa, 2003. Print.

Verhaar, J.W.M. Pengantar linguistik. Gadjah Mada University Press, 1984. Print. 